\title{
Perception of Stakeholders on Factors Responsible for Sports Facilities Defects in Selected Universities in South Western Nigeria
}

\author{
Oseghale G. E. ${ }^{1 * *}$ and Ikpo J. I. ${ }^{2}$ \\ ${ }^{1,2}$ Department of Building, Obafemi Awolowo University, Ile-Ife, Nigeria \\ Corresponding Author: *oseghaleehis@oauife.edu.ng
}

https://doi.org/10.36263/nijest.2020.01.0187

\begin{abstract}
The study assessed the perceptions of stakeholders on factors causing sports facilities defects in selected universities established between 1957 and 1962 in South-West Nigeria by examining the strength of the identified factors responsible for sports facilities' defects in the selected universities. Data were collected using a structured questionnaire which was administered on sports men and women and maintenance personnel. The study incorporated all the fifteen sports featured at the Nigeria University Games Association (NUGA) competitions. Three federal universities were purposively selected because these have facilities for all the fifteen sports and have hosted national and international sporting events. Data obtained were analyzed using frequency distribution, percentages, mean response analysis and factor analysis. Using the mean response analysis, the result showed that the most severe factors responsible for sports facilities' defects were design deficiencies (3.67), intensity of use (3.53), level of exposure to climatic condition (3.41), inadequate maintenance funding (3.19), vandalism (3.18), moisture (3.17) and inadequate cash flow analysis (3.16). The study recommends that users of the facilities should be carried along at the designs stage to minimize design errors and also adequate fund should be provided to maintenance unit to guarantee adequate maintenance of sports facilities for optimal performance.
\end{abstract}

Keywords: Defects, Factors, Facilities, Sports, Stakeholders, Universities

\subsection{Introduction}

"Sports for all" is a stated goal of both governments and sports organizations the world over (Tangen, 2004; Spaaijj et al., 2018). Large grants and huge investments are used for the construction, maintenance and rehabilitation of different forms of sports facilities (Tangen, 2004). It is generally accepted that participation in sports provides an extensive range of benefits to individuals and the community as a whole. Engagement in sports is advised because it provides a variety of physiological, psychological and social benefits (World Health Organization (WHO) 2010; World Health Organization (WHO) 2014; Department of Health South Africa (DOHSA) 2015; Mthethwa, 2017). Involvement in physical activities has been revealed to decrease the risks of lifestyle related diseases such as cardiovascular diseases, obesity, hypertension, cancer and diabetes mellitus (WHO, 2010; McGuirk and Prentice, 2012).

Acknowledging the value of physical activities, tertiary institutions have invested massively in sports facilities and recreation resources (Webber and Mearman, 2005; Soleymani et al., 2012; Desrochers, 2013; University of the Western Cape (UWC), 2014; Mthethwa, 2017). Therefore, in order to achieve a balanced upkeep of these sports facilities including the structures, Robert (1995) emphasized the need for the crew to comprise personnel with appropriate technical knowledge and skills. The inference here is that for a bi- dimensional setting as this, the experts should have both the technical (engineering) and sports administration background (Adeniran and Ikpo, 2001). This may demand the incorporation of sports administrators into the engineering-based maintenance organization or conversely, contracting some workload requiring specialist attention if the organization is primarily managed by sports experts. 
Perhaps the greatest concern to the management of public utilities such as sports facilities is security of the facilities. Studies have shown that these facilities are prone to vandalism, graffiti, and theft, management inability to forecast in scientific terms the fund required periodically for maintenance (Seeley, 1987; Anderson, 1999; Akinpelu, 2002), probably because of the non-availability of facilities condition assessments data. Intensity of use of sports facilities could be a major source of defect, since usage of the sports facilities cannot practically be limited by management and this generate increasing failure rate of composite items such as closets, including septic tank, concrete and timber finishing surfaces where applicable, and the second aspect relates to trespassers who not only add to the design target but also use the area for other non-conforming purposes (Adeniran and Ikpo, 2001; Oseghale et al., 2019). Also, physical aggression and abrasion on the sports surfaces from athletes and vibrations induces on the sports building structures as a result of their trainings are other sources of deterioration on the sports facilities (Fischer et al., 2020). Corrosion of steel reinforcement especially from combine effects of chemicals such as chlorides, sulphate, acids are other sources of deterioration of sports facilities (Rossi et al., 2019).

The personality of an estate is marked by physical appearance. Most sports structures suffer severe exposure, which tells quickly on the finishing materials. The two most common materials (reinforced or plain concrete and timber) become unsightly when exposed to moisture and solar radiation. For concrete finishes, moss, lichens, moulds, plant growth and so on, mar appearance. Timber members rot due to fungi attacks and plant life, such as ivy and are completely destroyed by insects especially termites (Ikpo, 1990; Oseghale and Ikpo, 2014).

According to Adeniran and Ikpo (2001), client's brief for a new sporting facility often determines the long-term maintenance needs of the facility. The brief should indicate performance requirements and possible changes in use, as well as the future policy for operating, clearing and maintaining the facility. The effects of deterioration can be reduced by serious commitment towards maintenance by the users of the facility. The problem of deterioration can also be increased due to delay in responding to the problem by indifferent users. When maintenance is ignored (delayed or not executed at all) the effect is to aggravate it or increase the rate of sports facilities deterioration from year to year (AlSultan, 1996; Olubodun, 1996; Brumaru, 2002; Oseghale, 2016).

Neglecting maintenance of sport facilities imply increase in cost of operating facilities and a waste of related natural and financial resources (Jackson, 1989). This view was backed by Banful (2004) who noted that the financial effects of not attending to maintenance are often not only seen in terms of decreased asset life and premature replacement but also in increased cost of maintenance, operation and waste of related natural and financial resources. Most developing countries neglect maintenance and have no policy in dealing with deteriorating facilities (Oyenuga et al., 2012).

Maintenance organizations have always been complaining of inadequate funding. The implication of this is that the limited resources of the maintenance department have to be judiciously managed. Inadequate funding of maintenance activities all over the world made prioritization of maintenance demand a critical issue (Berger et al., 1991; Oladapo, 2004; Wing et al., 2016; Iversen, 2018; Parnell, et al., 2018; Lovett et al., 2020). Though the expenditure on maintenance is inadequate, poor management of the resource and maintenance services are also contributing greatly to spots facilities defects, poor service delivery, the spate of maintenance backlogs and poor user satisfaction (Olarewaju, 2011).

Defects in sports facilities can occur as a result of extreme environmental conditions such as solar radiation, moisture, wing, driving rains, high velocity water, soil erosion, frost, soil condition and lack of maintenance (Lavy and Bilbo, 2009; Oseghale, 2012). US Department of Education (2003a), noted that most of the facility problems are not only as a result of geographic or social-economic factors; but they are identified with maintenance staffing level, training and management practices.

Deficiencies in the design, poor detailing of working drawings, poor specification of construction materials, construction faults and maintainability issues if not attended to will result in more damages and costly repair works of sport facilities (Ikpo, 2006; Oseghale, 2012, Suffian, 2013; Oseghale and Ikpo, 2014). Also, the problem of poor workmanship, poor material specifications and design deficiency leads to distress in spalling bricked wall and causes vapour infraltration in buildings 
(Anderson, 1999; Muhamad, 2019; Yacob et al., 2019 and Ahmed, 2019). While, Atkinson (2003), Tayeh et al. (2019) and Ibitayo et al. (2020) noted that managerial errors accounted for more than $82 \%$ of all errors committed during construction of buildings.

It has been observed that in most organization, maintenance is perceived as merely about the mechanical and electrical system repairs and replacements in the facilities without much consideration given to civil and structural elements of the building. The implication of this is that the other elements and components in the facilities (e.g. building) unattended to deteriorate at a faster rate and more costly to maintain at a later date when it has completely failed or cease to perform the design function. Previous studies focused on deterioration of facilities and various maintenance practices in other sectors. Studies that have examined the deterioration and maintenance of sports facilities especially in tertiary institution are scanty. Also studies on the relationship between sport facilities defects and their maintenance are limited, hence this study. This paper therefore examines the strength of identified factors responsible for sports facilities defects in selected universities in South-West, Nigeria.

\subsection{Methodology}

The study population includes sportsmen and women and staff of maintenance department in the selected universities in South-West, Nigeria. The sampling frame covered all the universities in Southwestern Nigeria accredited by the National University Commission (NUC). Based on information provided on the Web of NUC (32) universities were identified in South Western Nigeria which includes; Seven Federal universities, nine State universities and sixteen private universities. 15 games featured by the Nigeria University Games Association (NUGA) namely: badminton, basketball, chess, cricket, football, handball, hockey, judo, squash racket, swimming, table tennis, taekwondo, tennis, track and field and volleyball were also included in the sampling frame.

The sample size includes; all NUGA sports and the attendant facilities, however, purposive sampling was used in the selection of the institutions. The choice of Universities selected for this study was dependent on the Universities having facilities for all the 15 NUGA sports, have participated in all the games and have hosted National and International sporting events.

A pilot survey conducted for this study revealed that only three federal universities [Obafemi Awolowo University, Ile-Ife; University of Ibadan and University of Lagos] had all the facilities for the 15 different sports and had hosted National and International sporting events. The respondents include: four members of NUGA technical committee, two coaches from each of the fifteen games in each university, the Director of Sports, two other members of the Sports Council, and two groundsmen from each University. From each selected University the Director of Works, four maintenance supervisors, two administrative staff, and eighteen maintenance operatives were selected from the Maintenance Units. From the user's perspective, six sports men and women (4 male, 2 female) were selected from each of the fifteen games in the selected Universities. The total sample size for the respondents was four hundred and fifty-four.

\subsection{Results and Discussion}

The respondents were asked to indicate their perception in a 5-point scale ranging from 1 - very low, 2 - low, 3 - moderate, 4 - high and 5 - very high on the strength of factors responsible for sports facilities defects. The result of the frequency of occurrence of the factors is evaluated in Table 1. 
Table 1: Factors responsible for sports facilities defects as perceived by respondents

\begin{tabular}{|c|c|c|c|}
\hline Factors & Mean & Standard deviation & Ranking \\
\hline Design deficiencies & 3.6667 & 4.5935 & 1 \\
\hline Intensity of use & 3.5256 & 1.2031 & 2 \\
\hline Level of exposure to climate condition & 3.4125 & 1.2895 & 3 \\
\hline Inadequacy of maintenance funding & 3.1923 & 1.2899 & 4 \\
\hline Vandalism & 3.1818 & 1.3546 & 5 \\
\hline Moisture & 3.1728 & 1.3397 & 6 \\
\hline Inadequate cash flow analysis & 3.1605 & 1.3082 & 7 \\
\hline Chang of use of facilities & 3.1519 & 1.2618 & 8 \\
\hline Plant growth & 3.1235 & 1.3075 & 9 \\
\hline Maintainability issues & $3 . .0988$ & 1.4018 & 10 \\
\hline Construction faults & 2.9877 & 1.2698 & 11 \\
\hline Driving rain & 2.9877 & 1.2196 & 11 \\
\hline Solar radiation & 2.9750 & 1.1360 & 13 \\
\hline Wind & 2.9750 & 1.2425 & 13 \\
\hline Attack by insect & 2.9750 & 1.3310 & 13 \\
\hline Lack of maintenance & 2.9383 & 1.4521 & 16 \\
\hline Corrosion & 2.9375 & 1.2049 & 17 \\
\hline Vibration & 2.9103 & 1.2399 & 18 \\
\hline Soil condition & 2.8642 & 1.2425 & 19 \\
\hline Attack by Rodents & 2.8642 & 1.2723 & 19 \\
\hline Poor specification of materials & 2.8312 & 1.2503 & 21 \\
\hline Termite attack & 2.8101 & 1.2411 & 22 \\
\hline Dusting & 2.7375 & 1.2091 & 23 \\
\hline Physical aggression & 2.7284 & 1.2749 & 24 \\
\hline Chemical agencies & 2.7250 & 1.2726 & 25 \\
\hline Attack by algae, mosses & 2.7051 & 1,2495 & 26 \\
\hline Damage cause by high velocity water & 2.6914 & 1.2614 & 27 \\
\hline Abrasion & 2.6456 & 1.3111 & 28 \\
\hline Inadequate detailing of working drawing & 2.6250 & 1.2157 & 29 \\
\hline Attack by fungi & 2.6173 & 1.2406 & 30 \\
\hline Sulphate attack & 2.5750 & 1.1883 & 31 \\
\hline Erosion & 2.5556 & 1.2247 & 32 \\
\hline Crystallization of salts & 2.5443 & 1.2890 & 33 \\
\hline Frost & 2.4375 & 1.2411 & 34 \\
\hline Acid attack & 2.3250 & 1.2890 & 35 \\
\hline
\end{tabular}

The analysis revealed that the highest rated factors were found to be design deficiencies (3.67), intensity of use (3.53), level of exposure to climatic condition (3.41), lack of maintenance funding (3.19), vandalism (3.18), moisture (3.17), inadequate cash Flow analysis (3.16), change of use (3.15), plant growth (3.12), maintainability issues (3.10), driving rain (2.99), construction faults (2.99), wind (2.98), attack by insect (2.98) and lack of maintenance (2.94).

The study explored factor analysis to reduce the factors to principal components. The value of Kaiser - Meyer - Olkin (RMD, 0.710) measure of sampling adequacy test carried out (Table 2) showed that the data collected were adequate for the analysis and the Barlett's test of sphericity $(0.000)$ was highly significant. Thus, the data upon which the analysis was carried out were reliable. The total variance explained by the factors ( 35 factors) is shown in Table 2. In all (7) components were extracted via principal component analysis with Eigen values greater than 1.000. The extracted seven (7) components explain approximately 69\% variability in the original thirty five (35) variables. The rotation sums of squared loadings revealed percentage of variables accounted for by extracted components as listed in a uniformly distributed manner of $37.87 \%, 6.97 \%, 6.33 \%, 5.67 \%, 4.72 \%$, $4.02 \%$ and $3.82 \%$ respectively (Table 3 ).

Table 2: Factor analysis - KMO index

\begin{tabular}{lll}
\hline \multicolumn{2}{l}{ Kaiser-Meyer-Olkin and Bartlett's Test } \\
\hline \multicolumn{2}{l}{ Kaiser-Meyer-Olkin Measure of Sampling Adequacy. } \\
Bartlett's Test of Sphericity $\quad$ Approx. Chi-Square & .710 \\
& Df & 1538.319 \\
& Sig. & 595 \\
& .000 \\
\hline
\end{tabular}


Table 3: Factor analysis - total variance explained

\begin{tabular}{llcl}
\hline Factor & Total & Percentage of Variance & Cumulative percentage \\
\hline Biological Agencies & 13.256 & 37.874 & 37.874 \\
Human error related factors & 2.441 & 6.974 & 44.847 \\
Chemical and Physical Agencies & 2.215 & 6.327 & 51.175 \\
Physical Agencies & 1.984 & 5.670 & 56.844 \\
Climatic Agencies & 1.650 & 4.715 & 61.560 \\
Chemical Agencies & 1.406 & 4.016 & 65.576 \\
Maintenance factors & 1.338 & 3.824 & 69.399 \\
\hline
\end{tabular}

By considering a cut-off point for the score loading with absolute value greater than 0.500 , the components and the corresponding critical factors loading are presented in Table 4.

Table 4: Factor analysis - rotated component matrix

\begin{tabular}{|c|c|c|c|c|c|c|c|}
\hline \multirow[b]{2}{*}{ Factors } & \multicolumn{6}{|c|}{ Components } & \multirow[b]{2}{*}{ Factor 7} \\
\hline & Factor 1 & Factor 2 & Factor 3 & Factor 4 & Factor 5 & Factor 6 & \\
\hline Termite attack & .853 & & & & & & \\
\hline Attack by insect & .818 & & & & & & \\
\hline Attack by Algae and Mosses & .752 & & & & & & \\
\hline Attack by Rodents & .731 & & & & & & \\
\hline Attack by fungi & .563 & & & & & & \\
\hline $\begin{array}{l}\text { Inadequate detailing of } \\
\text { working drawings }\end{array}$ & & .724 & & & & & \\
\hline Poor specification of materials & & .704 & & & & & \\
\hline Inadequate cash flow analysis & & 642 & & & & & \\
\hline Lack of Maintenance & & .604 & & & & & \\
\hline Construction faults & & .593 & & & & & \\
\hline Vibration & & .551 & & & & & \\
\hline Vandalism & & .532 & & & & & \\
\hline Abrasion & & & .832 & & & & \\
\hline Physical Aggression & & & .823 & & & & \\
\hline Acid attack & & & .806 & & & & \\
\hline Crystallization of salts & & & .678 & & & & \\
\hline $\begin{array}{l}\text { Damage caused by high } \\
\text { velocity water }\end{array}$ & & & & .808 & & & \\
\hline Erosion & & & & .806 & & & \\
\hline Dusting & & & & .744 & & & \\
\hline Plant growth & & & & .534 & & & \\
\hline Wind & & & & & .762 & & \\
\hline Moisture & & & & & .653 & & \\
\hline Soil Condition & & & & & .635 & & \\
\hline Solar Radiation & & & & & .593 & & \\
\hline Driving Rain & & & & & .513 & & \\
\hline Chemical agencies & & & & & & .685 & \\
\hline Corrosion & & & & & & .611 & \\
\hline Intensity of Use & & & & & & & .787 \\
\hline Maintainability issues & & & & & & & .511 \\
\hline
\end{tabular}

The first component in the analysis is mostly correlated with attack of the sports facilities by biological agencies. This component has Eigen value of 13.26 and percentage variance of $37.87 \%$ with factors including termite attack $(0.853)$, attack by insect $(0.818)$, attack by algae and mosses $(0.752)$ attack by rodents $(0.731)$ and attack by fungi $(0.563)$. The outcome of the study reveals that the material used for the construction of the floors of indoor sports hall, roof truss, skirting boards, office furniture and doors were majorly timber. There are over 2000 known species of termites in the tropics and they are broadly classified as dry wood and subterranean termites. Dry wood termites confine themselves entirely within the timber and need no contact with the ground, while the subterranean are more wide spread and need to maintain contact with the soil. They both infested and cause destruction of timber by constructing tubes in the internal structure of timber. These reasons underscored the higher scoring of termites as a factor responsible for sports facilities defects.

Insect attack is generally confined to timber, but some other materials derived from organic fibers may be infected. Beetles of one kind or another infest timber because the organic nature of the material is favourable to the grub's life cycle of hatching, growing and emerging. The effect is to reduce the cross-sectional area of the timber and also reduce its strength and therefore shorten the 
durability of the material. Algae growth resembles dirt deposit on external paint surface and porous concrete. Plant life in the form of moss if allow to develop will cause deterioration of material for the construction of sports buildings. The damage is done by the penetration of roots into the crevices as they grow to extract moisture from the damp materials. Rodents may cause considerable damage to timber and other organic materials. Fungi are parasitic and attached themselves to the surfaces which supplies nutrients. Fungi attack occurs only in the presence of sufficient persistent moisture, oxygen, and cellulose in the timber, and they are the chief causes of decay of timber. Findings agreed with Ikpo (1990) \& (2006), Adeniran and Ikpo (2001), Oseghale (2014) and Oseghale and Ikpo (2014).

The second component is highly correlated with man-oriented decay. This component has Eigen value of 2.44 and percentage variance of $6.97 \%$ with inadequate detailing of working drawings $(0.724)$, poor specification of materials (0.704), inadequate cash flow (0.642), and lack of maintenance (0.604), construction faults (0.593), vibration (0.551) and vandalism (0.532). The constructional details of working drawings dictate to the builder what to build. Examples are non - adherence to the recommended minimum eaves projection of $600 \mathrm{~mm}$ that expose external walls to significant moisture resulting from driving rain. Depths and widths of footings, specific foundation types, and degree of inclination of elements such as roofs are details commonly observed to be missing in working drawings. These inadequacies in detailing of working drawings lower the quality of the final product. Poor specification of composite building materials may produce devastating results. The findings agree with Watt (1999), Calder (1997) and Ikpo (2006) who opined that inappropriate materials applied to building and poor expert decision making caused building defects and lower construction quality. Inadequate cash flow agreed with Ikpo, (2006) who opined that cash constraints lead to project delays and in extreme cases abandonment. Neglecting maintenance of sports facilities and delay in attending to the problem of indifferent users as in the case of sports facilities could heighten the problem of deterioration. This finding is in agreement with Al-Sultan (1996), Olubodun (1996) and Brumaru (2002) who opined that the effects of ignoring maintenance is to aggravate or increase the rate of facilities deterioration from year to year. Fault construction from site personnel can promote the deterioration of sports facilities through bad workmanship, inadequate supervision and the substitution of poor materials. This finding agreed with Atkinson (2003), Tayeh et al. (2019) and Ibitayo et al. (2020) who found that managerial errors accounted for more than $82 \%$ of all errors committed during construction of buildings. The finding also agreed with Anderson (1999), Muhamad (2019), Yacob et al. (2019) and Ahmed (2019) who found that distress on the spalling brick wall that caused vapour infiltration in building was due to deficiencies in workmanship, material and design.

The third component is most highly correlated with chemical and physical agencies that cause decay of sports facilities. The component has Eigen value of 2.22 and percentage variance of $6.33 \%$. It is clustered around with abrasion (0.832), physical aggression (0.823), acid attack (0.806) and crystallization of salts (0.678). Abrasion caused by either athletes, pedestrians or equipment continuously passing over timber and concrete floor particularly in play surfaces, are subject to wear. Physical force imposes by the athletes continuous sliding on the concrete and timber finished surface during training and competition accelerate the process of deterioration of these materials. This underscores the high rating of physical aggression as a factor responsible for sports facilities defects which agreed with the findings of Fischer et al. (2020). Atmospheric gases such as sulphur dioxide, carbon dioxide in the presence of moisture contribute to the formation of acid that attack certain materials such as metals which are used in the fencing of outdoor courts and concrete for hard courts areas. Crystallization of salts may be present initially in certain building materials or may be conveyed into them by movement of moisture from the ground. When crystallization of salt occurs within the pores of the surface layer it may cause gradual erosion or flaking of the finished materials such as paints and surface disfiguration, but when it takes place below the surface it can cause more serious problem. This agrees with the findings of Rossi et al. (2019) who opined that deterioration of sports facilities as a result of the corrosion of steel reinforcement were from the combine effects of chemicals such as chlorides, sulphate and acids attacks.

The fourth component is highly correlated with environmental factors. This component has Eigen value of 1.98 , percentage variance of $5.67 \%$ and had factor loading of damage by high velocity water (flooding) (0.808), erosion (0.806), dusting (0.744) and plant growth (0.534). In places where drainages and water channels are not properly constructed or not constructed at all flooding and erosion have serious consequences and damaging effects on the fields and concrete courts. Dusting is 
most encountered on floors where traffic and abrasion are heavy such as basketball, handball, tennis and volleyball courts. Also increased water at the surface of the courts after rainfall raised the water cement ratio and reduced the strength of that portion of concrete and subsequently subjected to abrasion. Trees also grow around buildings and outdoor hard court areas, and at times have their roots shooting gradually along horizontal plane. The effects on the building and hard courts areas are that the foundation walls within the areas suffer severe damage and manifest in the form of cracks. These underscore the very high rating of these factors as responsible for sports facilities defects.

The fifth component is most highly correlated with climatic factors with Eigen value of 1.65, and percentage variance of $4.72 \%$. This component has wind (0.762), moisture (0.653), soil condition (0.635), solar radiation (0.593) and driving rain (0.513). Wind causes direct physical damage by the removal of parts of the roof or the whole roof of sports buildings and covered pavilions. This finding agreed with Ikpo, (2006) who opined that wind cause serious damage on poorly secured roof structures. Moisture is the principal agent of deterioration and probably also the agent with the greatest influence on the properties of materials. The finding is in agreement with Son and Yuen (1990); Ikpo (1990); Obiegbu (2003); 1kpo (2006); Oseghale (2014); and Oseghale and Ikpo (2014). Soil movement which may result from geological processes such as folds, faults, compression of layers of peats, swelling and shrinkage of clay soils adversely affects the foundations of sport buildings and hard courts areas. Solar radiation causes thermal expansion which in buildings manifests as thermal expansion cracks in brickwork, blockwork and concrete if ends were restrained. The effect of driving rain is that the vertical surface facing the received rainwater at an angle. The resultant stresses set up may lead to disintegration of the surface layer.

The sixth component which mostly correlated with chemical agencies has Eigen value of 1.41 and accounted for $4.02 \%$ of the total variance. This component has the factor loadings of chemical agencies (0.685) and corrosion of metals (0.611). Metal poles and wire gauze were predominately used in the fencing of outdoor courts in the study areas. When metals are exposed to moisture in the presence of oxygen corrosion takes place. This is in agreement with Rossi et al. 2019.

The seventh component in the analysis is most highly correlated with maintainability issues and intensity of use. This component has Eigen value of 1.34 and percentage variance of $3.82 \%$ with intensity of use (0.787) and maintainability issues $(0.511)$. Intensity of use of sports facilities could be a major source of defects. The high scoring of intensity of use is justified because sports facilities like any other hospitality facilities are such that provide services (round the clock) all the time. The findings agreed with Ikpo (1990), Adeniran and Ikpo (2001), Ikpo (2009) and Oseghale (2016). Indoor sports buildings are usually design with a high head room to enable athletes have their games. Some of the maintainability issues commonly observed were failure to provide accessibility to ceiling space for the purposed of maintenance.

\subsection{Conclusions}

The study assessed the strength of each of the identified factor responsible for sports facilities defect. The finding revealed that the most severe factors responsible for sport facilities defects were: design deficiencies, intensity of use, and level of exposure to climatic condition, vandalism, moisture and inadequate cash flow analysis. The study found that attack of sport facilities by biological agencies were the first components correlated in the analysis, while the second component was highly correlated with man-oriented decay. And the third component was most highly correlated with chemical and physical agencies that cause decay of sports facilities. Physical force imposes by the athletes continuous sliding on the concrete and timber sports finished surface during training and competition accelerate the process of deterioration of these materials. The study found design defects, high intensity of use, high level of sports facilities exposure to climatic and environmental condition and poor maintenance funding as the most influencing factors responsible for sports facilities defects. The study, therefore, recommends that the users of sports facilities (athletes and members of sports council) be carried along in the design of sports facilities to improve their designs and adequate fund be made available by the government to enable maintenance units to stockpile the materials that fail frequently as a result of the high intensity of use of these facilities to minimize maintenance downtime and improve their reliability. 


\section{References}

Adeniran, S. O. and Ikpo, I. J. (2001). Management strategies for university sports facilities. African Journal for Physical, Health Education, Recreation and Dance, 7(2), pp. 349-360.

Ahmed, A. E. (2019). Assessment of Causes of Construction Building Defects in Debre Birhan University, North Showa, Amhara, Ethiopia. American Journal of Civil Engineering and Architecture, 7(4), pp. 152-156.

Akinpelu, J. A. (2002). The need for code of conduct, building regulations and bye laws for the Building Industry in Nigeria. The Professional Builder, Nigeria Institute of Building, 2(1), pp. 11-14.

Anderson, L. M. (1999). Spalling brick-material, design or construction problem. Journal of Perform Construction Faculty, pp. 163-171.

Al-Sultan, K. S. (1996). Maintenance in Saudi Arabia: needs and recommendations for improvement. Journal of Quality in Maintenance Engineering, 2(4), pp. 5 - 16.

Banful, E. (2004). A Stitch in Time Saves Nine; Cultivating A Maintenance Culture in Ghana. An Article Presented at Seminar on Maintenance Culture, in Ghana, $16^{\text {th }}$ March, Ghana.

Berger, L., Greenstein, J., Hoffman, M. and Uzan, J. (1991). Practical application of models for pavement maintenance management. A. S. C. E. Journal of Transportation Engineering, 117(9), pp. $2065-2078$.

Brumaru, M. (2002). Need and strategy in housing rehabilitation: The Romanian case, in Ural, O. Abrantes, V. \& Tedeu, A. (eds) Ibid. 3, pp. 1975-1984.

Calder, A. J. (1997). Construction Quality Auditing. Journal of Management in Engineering, 13(6), pp. 26-28.

Department of Health South Africa (DOHSA) (2015). Strategy for the prevention and control of obesity in South Africa 2015 - 2020. [Online] Available at: http://cdn.24.co.za/files/Cms/General/d/4776/e9776ca8f6a44f3099dbde892bb0afbb.pdf, [Accessed 23 February 2020].

Desrochers, D. M. (2013). Academic Spending Versus Athletic Spending: Who Wins? Delta cost projects at American Institute for Research. [Online] Available at: http://www.air.org/sites/default/files/downloads/report/Academic-Spending-vs-AthleticSpending.pdf, [Accessed 21 February 2020].

Fischer, A., Harrison, R., Lancelot, F. and Hargreaves, J. (2020). Assessment and Control of Structural Vibration in Gyms and Sport Facilities. Dynamics of Civil Structures, 2, pp. 61-74.

Ibitayo, M. S., Okolie, K. C., Ezeokoli, F. O. and Ogunoh, P. E. (2020). Factors Affecting Maintenance of Buildings in Petroleum Training Institute, Uwvie and Delta State University Abraka, Delta State, Nigeria. Archives of Current Research International, 19(4), pp. 1-9.

Ikpo, I. J. (1990). Deterioration Phenomena of Selected Housing Estates in South Western Nigeria, Unpublished Ph.D thesis, Department of Building, O.A.U, Ile-Ife.

Ikpo, I. J. (2006). Building Maintenance Management Oron: Manson Publishing company.

Ikpo, I. J. (2009). Maintainability Indices for Public Building Design. Journal of Building Appraisal. 4 (4), pp.321-327.

Iversen, E. B. (2018). Public Management of Sports Facilities in times of Austerity. International Journal of Sport Policy and Politics, 10(1), pp. 79-94. 
Jackson, J. A. (1989). Facility Reliability and Maintainability: An Investigation of the Air Force Civil Engineering Recurring Work Program. Wright-Patterson Air Force Base, OH: Air Force Institute of Technology

Lavy, S. and Bilbo, D. L. (2009). Facilities Maintenance Management Practice in Large Public Schools, taxas. Journal of facilities, 27(1/2), pp. 5-20. Emerald Group Publishing Limited.

Lovett, E., Bloyce, D. and Smith, A. (2020). Delivering a Sport Participation Legacy from the London 2012 Olympic and Paralympic Games: Evidence from Sport Development Workers in Birmingham and their Experience of a Double-Bind, Leisure Studies, doi: 10.1080/02614367.2020.1738534

McGuirk, E. and Prentice, G. (2012). Physical activity, its relationship with psychological Nigeria, Wellbeing and self-perception, and in keeping us all psychologically healthier. Unpublished BA thesis. DBS School of Arts. Department of Psychology. Dublin, Ireland

Mthethwa, M. M. (2017). Factors affecting participation in sport and recreation of students staying in residences at the University of KwaZulu-Natal. [Online] Available at: https://researchspace.ukzn.ac.za/bitstream/handle/10413/14788/Mthethwa Mthokozisi Michael 2017 .pdf? sequence $=1$ \&isAllowed=y, [Accessed 10 March 2020].

Muhamad, T. R. (2019). Building Component Defects Due to Land Settlement: A Case Study of Miri Industrial Training Institute. Journal of Industry, Engineering and Innovation, 1(1), pp. 1-8.

Obiegbu, M. E. (2003). Factors influencing the defects and performance of Building. Journal of National Institute of Building, pp. 53-61.

Oladapo, D. A. (2004). An Evaluation of the Maintenance Management of the Staff Housing Estates of Selected First Generation Universities in South Western Nigeria. Unpublished Ph.D thesis, Department of Building, O. A. U, Ile-Ife.

Olarewaju, A. A., Mohammed, F. K. and Arazi, I. (2011). Appraisal of Building Maintenace Management Practices of Malysian Universities. Journal of Building Appraisal, 6(3/4), pp. 51-61.

Olubodun, F. O. (1996). An Empirical Approach to the Evaluation of Factors in Local Authority Housing Maintenance Requirements in the City of Manchester. Unpublished Ph.D Thesis Department of Surveying, University of Salford, Salford, England.

Oseghale, G. E. (2012). Maintenance management strategy used for selected Industrial Estate in Lagos State, Nigeria, Unpublished Mphil thesis, Department of Building, Obafemi Awolowo University, Ile-Ife.

Oseghale, G. E. (2014). Impact of Maintenance Strategies on the Performance of Industrial Facilities in selected Industrial Estate in Lagos state Nigeria. American Journal of Engineering research, 3(8), pp. 171-179.

Oseghale, G. E. and Ikpo I. J. (2014). Evaluation of industrial facilities defects in selected Industrial Estates in Lagos State, Nigeria. Journal of Civil Engineering dimension, 16(2), pp. 104-111.

Oseghale, G. E. (2016). Maintenance management strategy for sport facilities in selected universities in Southwestern Nigeria, Unpublished Ph.D thesis, Department of Building, Obafemi Awolowo University, Ile-Ife.

Oseghale, G. E., Ikpo, I. J., Oseghale, B. O. and Adetooto, J. D. (2019). Perception of stakeholders on the maintenance management strategy for sport facilities in selected universities in Southwestern Nigeria. British Journal of Marketing Studies, 7(5), pp. 87-99. 
Oyenuga, S. O., Akinsola, O. E., Hussanni, P. O. and Fatokun, A. O. (2012). Maintenance of University Facilities in Developing Country: A Case Study of Lagos State University, Nigeria. Mediterranean Journal of Social Science, 3(1). pp. 69-75.

Parnell, D., May, A., Widdop, P., Cope, E. and Bailey, R. (2018). Management Strategies of nonprofit Community Sport Facilities in an Era of Austerity. European Sport Management Quarterly, 19(3), pp. 312-330.

Robert, L. (2012). Impact of Campus Recreational Sports Facilities and Programs on Recruitment and Retention among African American Students: A Pilot Study. Recreational Sports Journal, 33(1), pp. 25-34.

Rossi, E., Nijland, T., Copuroglu, O., Polder, B. and Savija, B. (2019). The Influence of defects at the steel/concrete Interface for pitting corrosion Initiation Studied through X-ray Computed Tomography and image analysis. Construction and Building Materials, 235, pp. 1-7.

Seeley, I. H. (1987). Building maintenance, 2nd Edition, Macmillan, London.

Soleymani, M., Farshard, A. Z. and Fharzard, G. (2012). A study of the relationship between the quality of service and customers satisfaction with recreational sports programmes with regards to moderating role of identity. European Journal of Sports and Exercise Science, 1, pp. 29-35.

Spaaijj, R., Schulenkork, N., Jeans, R. and Oxford, S. (2018). Participatory Research in Sports-Fordevelopment: Complexities, Experiences and Missed Opportunities. Journal of Sport Management Review, 21, pp. 25-37.

Suffian, A., (2013). Some common maintenance problems and building defects: our system for simulating construction processes. Automation in Construction, 16(5), pp.576-58.

Tangen, J. O. (2004). Embedded Expectations, Embodied Knowledge and Movements that Connect: A System Theoretical Attempt to Explain the Use and Non-use of Sports Technology, Stockholm. International Review for the sociology of sport, 39(1), pp.7-25.

Tayeh, B. A., Hamad, R. J. A., Alaloul, W. S. and Almanassra, M. (2019). Factors Affecting Defects Occurrence in Structural Design Stage of Residential Buildings in Gaza Strip. The Open Civil Engineering Journal, 13, pp. 129-139.

University of the Western Cape (UWC) (2014). Major Facelift for UWC sports stadium. [Online] available online at: https://www.uwc.ac.za/News/Pages/Sport- stadiumupgrade.aspx. [Accessed 12 March 2020]

US Department of Education (2003a). Planning Guide for Maintaining School Facilities.

Watt, D. (1999). Building Pathology: Principles and Practices. Oxford: Blackwell Science.

Webber, D. J. and Mearman, A. (2005) Student participation in sporting activities. School of Economics. University of the West of England. Bristol, United Kingdom. [Online] Available at: http://dx.doi.org/10.1080/00036840601019216, [Accessed 19 March 2020].

Wing, A. C. K., Mohammed A.H., and Abdullah M.N. (2016) A review of maintenance priority setting methods. International Journal of Real Estates Studies. 10(2): 36-43.

World Health Organization (WHO) (2010). Global status report on non-communicable diseases. [Online] Available at: http/www.whoint/nmh/publication/2010/en, [Accessed 6 April 2018].

World Health Organization (WHO) (2014). Global status report on non-communicable diseases. [Online] 
http://apps.who.int/iris/bitstream/10665/148114/1/9789241564854 eng.pdf?ua=1, [Accessed 5 March 2020].

Yacob, S., Ali, A. S. and Au-Yong, C. P. (2019) Establishing Relationship Between Factors Affecting Building Defects and Building Condition. Journal of Surveying, Construction and Property, 10(1), pp. 31-41.

Cite this article as:

Oseghale G. E. and Ikpo J. I., 2020. Perception of Stakeholders on Factors Responsible for Sports Facilities Defects in Selected Universities in South Western Nigeria. Nigerian Journal of Environmental Sciences and Technology, 4(1), pp. 127-137. https://doi.org/10.36263/nijest.2020.01.0187 